\title{
Beliefs and Knowledge of the Public about People Who Stutter: Age and Sex Comparisons
}

\author{
HeeCheong Chon \\ Department of Speech-Language Pathology, Chosun University, Gwangju, Korea
}

Correspondence: HeeCheong Chon, $\mathrm{PhD}$ Department of Speech-Language Pathology, Chosun University, 309 Pilmun-daero, Dong-gu, Gwangju 61452, Korea

Tel: +82-62-230-7857

Fax: +82-62-230-6271

E-mail: hchon@chosun.ac.kr

Received: July 5, 2016

Revised: August 18, 2016

Accepted: August 27, 2016

\begin{abstract}
Objectives: The purpose of this study was to explore the beliefs and assess the level of knowledge about people who stutter (PWS) in the Korean public. Methods: The responses of 298 Korean adults were collected for the 'beliefs about PWS', one of the subcategories in the Public Opinion Survey on Human Attributes-Stuttering (POSHA-S). The subcategories consisted of four components (traits/personality, help source, cause, and potential). The four components and the 'beliefs about PWS', which is the mean score of all components, were analyzed and compared among ages (four groups) and sex. The Alabama Stuttering Knowledge test (ASK) score was also compared. Results: There was no significant interaction or main effect between age and sex for the 'beliefs about PWS' and three of the component (traits/personality, cause, potential) scores. However, age had a significant effect on 'help source', where the group over 50 years of age showed a significantly higher mean score than the 20-year-old group. The ASK score did not indicate any effect but there were significant correlations between the ASK and 'cause' scores and the ASK and 'potential' scores. Conclusion: The findings suggest that, regardless of age or sex, beliefs about PWS held by the public were not negative in general, although they were not very knowledgeable about stuttering/PWS. Providing more interpersonal and educational support regarding stuttering would help the public increase their positive beliefs about stuttering.
\end{abstract}

Keywords: People who stutter (PWS), Beliefs, Knowledge, POSHA-S, Age, Sex 낙인(stigma)은 특정 사회집단 혹은 사회적 맥락에서 어떠한 특 성이나 속성, 혹은 개인을 평가절하하거나 가치가 낮다고 여기는 것을 의미하며(Boyle, 2013; Goffman, 1963) 대중적 낙인(public stigma)과 자기 낙인(self-stigma)으로 분류할 수 있다. 이 중 대중적 낙인은 “사회구성원이 낙인이 찍힌 특정 대상에게 보이는 부정적 인 인지적, 정서적, 행동적 반응”을 의미하며(Boyle, 2013, p. 1517), 특정 대상에게 고정관념(stereotype)을 가지고 있거나 편견을 보이 거나, 차별을 하는 방식으로 표출된다(Corrigan \& Watson, 2002; Link \& Phelan, 2006). 자기 낙인은 낙인이 찍힌 대상 스스로가 사 회구성원이 보이는 고정관념이나 편견, 차별을 받아들이고 내재화 (internalization)시키는 것이다(Boyle, 2013; Corrigan, Larson, \& Rüsch, 2009).

기능, 장애, 건강의 국제적 분류(International Classification of Functioning, Disability and Health; World Health Organization,
2001)의 관점에서 말더듬는 사람(people who stutter, PWS)은 자신 의 말더듬 행동과 말더듬으로 인한 부수행동으로 인해 활동/참여의 제한을 겪게 된다(Chon \& Yaruss, 2015; Yaruss \& Quesal, 2004). 이러한 제한은 개인적, 사회적, 직업적인 측면에서 광범위하게 나타 난다. 보다 구체적으로 타인과 구어 의사소통을 하거나 새롭게 사 회적 관계를 맺는 데 제한을 겪을 수 있으며, 직업의 선택이나 직장 에서의 성공에도 부정적인 영향을 미칠 수 있다(Yaruss \& Quesal, 2004). PWS가 곆게 되는 다양한 어려움은 환경적 요인으로 인해 심화될 수 있으며 궁극적으로 PWS의 삶의 질에 부정적인 영향을 미칠 수 있다(Chon \& Yaruss, 2015; Craig, Blumgart, \& Tran, 2009). 말더듬 분야 연구자들은 PWS가 겪는 이러한 어려움의 원인과 해 결책을 찾고 이를 임상에 적용하기 위하여 다양한 연구를 진행하 고 보고하였다. 그 중 대표적인 것이 PWS와 의사소통을 하는 청자 가 PWS에 대해 가지고 있는 대중적 낙인, 즉, 고정관념을 포함한 
말더듬에 대한 신념 연구이다. 고정관념은 사회가 가지고 있는 고 정된 선입견으로 인해 특정 집단에 속한 사람의 개인적 특성이나 능력을 단순하게 범주화시키거나 어떠한 사실을 축소해서 가지고 있는 믿음을 의미한다(Fiske, 1998; Park \& Yi, 2001). 국내외에서 다양한 청자 집단을 대상으로 이루어진 PWS에 대한 고정관념 연 구는 국가나 문화적 특성과 상관 없이 대부분 PWS에 대한 청자의 부정적인 고정관념을 보고하고 있다(Craig, Tran, \& Craig, 2003; Lass, Ruscello, Pannbacker, Schmitt, \& Everly-Myers, 1989; Lass et al., 1992, 1994; Lee, 2013, 2014; Ruscello, Lass, Schmitt, \& Pannbacker, 1994; Sim, 2000; Woods \& Williams, 1976; Yairi \& Williams, 1970). 예를 들어, Lass와 동료들(1989, 1992, 1994)과 Ruscello 등(1994)은 PWS에 대한 인식을 알아보기 위해 언어재활사, 교 사, 특수교사 및 학교 행정담당자를 대상으로 가상의 PWS를 제시 하고 그들과 관련된 형용사를 적게 하는 방법을 사용하였다. 연구 결과, 청자 집단에 상관없이 대다수의 형용사가 부정적인 의미를 가지고 있었으며 PWS의 성격 특성(예, 수줍은, 긴장한)과 관련 있 었다고 하였다. Craig 등(2003)은 PWS와 직접적으로 접촉해 본 경 험이 없는 일반인을 대상으로 말더듬에 대한 정의를 제시한 후 PWS에 대한 고정관념을 살펴본 결과, PWS가 수줍어하고, 내성적 이고, 자신감이 결여되어 있고, 불안해 한다는 것에 동의하는 일반 인의 비율이 동의하지 않은 일반인에 비해 유의하게 높았다고 하였 다. 국내에서 일반인과 말더듬 성인, 언어병리학 관련지식이 있는 학생을 대상으로 PWS에 대한 고정관념을 비교했던 $\operatorname{Sim}$ (2000)은 집단마다 다른 고정관념 특성이 나타나기도 하였으나 모든 집단이 공통적으로 PWS가 긴장되어 있다는 부정적인 고정관념을 보였다 고 하였다. 말더듬에 대한 국내 교사와 언어재활사의 인식을 살핀 Lee $(2013,2014)$ 역시 응답자들이 PWS가 열등감이나 심리적인 문 제를 가지고 있으며, PWS를 특징짓는 성격이 있다고 생각하고 있 음을 보고하였다. 이와 같이 PWS의 성격특성에 대해 청자가 공통 적으로 생각하는 부정적인 고정관념은 최근에 말더듬 고정관념 (stuttering stereotype)이라는 용어로 사용되고 있다(Boyle, Blood, \& Blood, 2009; MacKinnon, Hall, \& MacIntyre, 2007).

성격특성 외에 말더듬 혹은 PWS에 대한 신념 연구는 주로 말더 듬의 원인과 사회적 관계나 직업에서 PWS의 잠재적인 가능성을 청자가 어떻게 생각하고 있는지에 대해 살피고 있다. 말더듬의 원인 을 살펴본 연구들은 청자가 말더듬이 정서적 혹은 심리적 이유 때 문이라고 생각하는 경우가 많았으며(Craig et al., 2003; de Britto Pereira, Rossia, \& Van Borsel, 2008; St. Louis et al., 2011; Jin, Zhao, Zhang, \& Van Borsel, 2001; Van Borsel, Verniers, \& Bouvry, 1999), 부모 때문이라고 생각하기도 하며(Craig et al., 2003; Lee, 2013, 2014),
말더듬의 원인이 복합적이라고 생각하기도 한다고 하여(Lee, 2013, 2014) 청자가 가지고 있는 말더듬의 원인에 대한 의견이 다양함을 보고하였다. 또한 말더듬의 원인이 무엇이라고 생각하는지에 따라 PWS에 대한 응답자의 태도가 바뀔 수 있다고도 하였다(Boyle et al., 2009). PWS의 잠재적인 가능성에 대한 청자의 신념을 살핀 연 구는 PWS가 인간 관계와 같은 사회적인 관계에는 문제가 없을 것 이라는 의견이 지배적이지만(St. Louis et al., 2011) PWS가 말더듬 때문에 직업적 성취와 관련하여 제한을 받을 것이라고 청자들이 생각하고 있으며(Gabel, Blood, Tellis, \& Althouse, 2004; Hurst \& Cooper, 1983; Schlagheck, Gabel, \& Hughes, 2009), 직업적인 성취 에 문제가 없다고 생각할 지라도 말더듬으로 인해 직업의 종류에 제한이 있을 수 있다는 의견을 보고하기도 하였다(Craig et al., 2003; St. Louis et al., 2011).

이와 같이 선행연구 결과는 전반적으로 청자가 말더듬 혹은 PWS 에 대해 부정적인 고정관념과 신념을 가지고 있음을 보고하고 있으 며, 이는 중요한 임상적 의의를 갖는다. 청자가 PWS에 대해 가지고 있는 인지적 측면인 고정관념과 신념이 편견이나 차별과 같은 정서 적/행동적 반응으로 나타날 수 있으며, 이는 환경적 요인의 일부로 서 PWS의 말더듬 혹은 더 나아가 그 사람의 삶에 영향을 미칠 수 있기 때문이다(Klassen, 2002; Lee, 2013).

PWS에 대한 부정적인 고정관념과 신념이 왜 생기는가에 대한 논의는 학자마다 다양하다. 고정관념의 경우, 말을 더듬지 않는 일 반인이 일시적으로 말을 더듬었던 경험과 그 당시의 느낌을 PWS에 게 투영한다는 관점이 있으며(기준점과 조정 휴리스틱, anchoring and adjustment heuristic) (Doody, Kalinowski, Armson, \& Stuart, 1993; MacKinnon et al., 2007; White \& Collins, 1984), PWS가 말 을 더듬을 때 보이는 긴장 같은 명백한 투쟁행동을 접하게 되면서 고정관념이 발생한다고 보는 관점도 있다(Kalinowski, Stuart, \& Armson, 1996). 또한 고정관념과 신념은 다양한 변인의 영향을 받 을 수 있다. 일관된 결론에 이르지는 못하였으나 선행연구는 PWS 에 대한 고정관념과 신념에 영향을 미칠 수 있는 인구통계학적 변 인(demographic variable)으로 성별, 연령, 교육 연수, PWS에 대한 친숙성, 말더듬 관련 지식을 제시하고 있다. 성별은 남성이 여성에 비해 부정적인 고정관념이나 신념을 가지고 있었다는 결과(Arnold, Li, \& Goltl, 2015; Burley \& Rinaldi, 1986; Schlagheck et al., 2009; Weisel \& Spektor, 1998)와 성별에 따른 차이가 없었다는 결과(Craig et al., 2003; Patterson \& Pring, 1991; St. Louis, 2012b)가 혼재되어 있어 추가적인 확인이 필요하다. 만일 일반인에게서 성별에 따른 인 식의 차이가 존재한다면, 그리고 선행연구 결과처럼 남성이 여성보 다 PWS에 대한 부정적인 인식이 높다면 이는 잠재적으로 PWS의 
직장생활이나 직업적 성취에 부정적인 영향을 미칠 수 있기 때문이 다. 연령 역시 일관된 결론에 이르지 못하였으나 말더듬에 대한 신 념이나 고정관념이 연령과 어느 정도는 관련 있는 것으로 보인다 (Al-Khaledi, Lincoln, McCabe, Packman, \& Alshatti, 2009; Arnold et al., 2015; de Britto Pereira et al., 2008; Van Borsel et al., 1999). 예를 들어, 높은 연령대 집단이 낮은 연령대 집단보다 말더 듬에 대한 신념이 부정적이거나 부정확했다는 연구 결과가(de Britto Pereira et al., 2008; Jin et al., 2001; Van Borsel et al.,1999) 있 는 반면 Arnold 등(2015)은 연령이 증가할수록 PWS에 대한 신념 이 긍정적이었다고 보고하였으며, Al-Khaledi 등(2009) 역시 40세 이상 연령집단이 말더듬에 대한 인식 관련 문항에서 39세 이하 연 령집단보다 긍정적으로 답하였다고 하였다. 하지만 선행연구는 연 령을 공변량으로 설정한 경우가 빈번하였으며, 다양한 연령대별로 비교가 이루어지지 않았기 때문에 연령에 따른 고정관념과 신념 특성을 명확하게 파악하지는 못하였다. 또한 고정관념이나 신념은 사회적 학습과 PWS와의 직간접적인 접촉을 통해 형성되기 때문 에 높은 연령대에서 말더듬과 관련된 특정 고정관념이나 신념이 뚜 렷하게 나타나거나 오히려 반대로 특정 고정관념이나 신념이 낮게 나타날 수도 있다. 따라서 연령을 독립변수로 설정하여 연령대별 말더듬 고정관념과 신념 특성이 어떠한지 알아볼 필요가 있다. 말 더듬 관련 지식의 경우, 일반인의 말더듬 관련 지식이 어느 정도인 지는 말더듬 혹은 PWS에 대한 신념이나 인식 연구를 통해 간접적 으로 살펴볼 수 있었으나 이러한 연구들은 청자의 지식 정도가 아 니라 청자의 의견을 분석하는 데 초점을 맞추어왔다. 따라서 PWS 에 대한 청자의 지식 정도를 직접적으로 파악하고, 지식과 말더듬 에 대한 태도간 관련성을 살피기 위해 말더듬 관련 문헌의 내용을 바탕으로 Alabama 말더듬 지식 검사(Alabama Stuttering Knowledge test, ASK; Crowe \& Cooper, 1977)와 같은 검사를 제작하여 연구가 진행되었다. 연구 결과, 다양한 청자 집단(부모, 교사집단)에 서 말더듬에 대한 지식이 많을수록 말더듬에 대한 태도가 긍정적 이었음을 보고하였다(Crowe \& Cooper, 1977; Crowe \& Walton, 1981; Tomczyk, 2004). 교육 연수와 PWS에 대한 친숙성 역시 다양 한 연구 결과를 보이고 있으나 일반적으로 교육 연수가 높을수록, 그리고 PWS에 친숙한 청자일수록 PWS에 대한 부정적인 고정관 념이나 신념이 적은 것으로 나타났다(Arnold et al., 2015; Klassen, 2001).

Public Opinion Survey on Human Attributes-Stuttering (POSHA-S)은 타당도와 신뢰도가 입증되었으며(St. Louis, 2005, 2012a, 2012b; St. Louis, Lubker, Yaruss, \& Aliveto, 2009; St. Louis, Reichel, Yaruss, \& Lubker, 2009) PWS에 대한 대중의 태도를 수량화시켜
체계적이고 구체적으로 측정할 수 있는 설문도구이다. 이 설문도구 의 말더듬 관련 문항들은 PWS에 대한 응답자의 인지적인 측면을 알아보는 'PWS에 대한 신념(beliefs about PWS)'과 PWS에 대한 응 답자의 정서적/행동적인 측면을 알아보는 'PWS에 대한 자기반응 (self-reactions to PWS)' 하위범주로 분류된다. 'PWS에 대한 신념' 범주에는 '특성/성격(traits/personality)', '도움의 출처(help source)', '말더듬의 원인(cause)', '잠재력(potential)'의 네 가지 구성요소가 존재한다. '특성/성격'은 앞서 기술하였듯이 말더듬 고정관념을 알 아볼 수 있는 문항들로 응답자가 PWS의 특성 혹은 성격을 어떻게 생각하고 있는지 측정한다. '말더듬의 원인'은 응답자가 말더듬 발 생의 원인이 무엇이라고 생각하는지 확인하는 것을 목적으로 한 다. '도움의 출처'는 언어재활사, 다른 PWS, 의사 중 PWS가 누구에 게 도움을 받아야 한다고 생각하는지 묻는다. 마지막으로 '잠재력' 은 PWS의 사회적 성취 및 직업적 성취와 같은 잠재적 가능성에 대 해 응답자가 어떻게 생각하는지 측정하게 된다.

PWS에 대한 태도에 영향을 미치는 인구통계학적 변인을 독립변 수로 사용하거나 가외변수로 통제하여 진행하는 연구는 PWS에 대한 일반인의 태도를 명확하고 구체적으로 파악할 수 있게 해준 다(Chon, 2016). 국내에서 이루어진 PWS에 대한 고정관념이나 신 념, 인식 관련 연구들은 교사, 일반인, 말더듬 성인, 언어재활사 등 다양한 집단을 대상으로 이루어졌지만(Lee, 2013, 2014; Sim, 2000) 연령과 성별 같이 고정관념과 신념에 영향을 미칠 수 있는 인구통 계학적 변인 간 비교는 이루어지지 않았다. 말더듬과 관련된 국내 일반인의 고정관념과 신념을 효과적으로 측정하기 위해 네 개 구 성요소를 포함하고 있는 POSHA-S의 'PWS에 대한 신념' 하위범 주를 사용하여 연령과 성별 간 비교가 이루어진다면 PWS에 대한 일반인의 의견을 다양한 측면에서 체계적으로 살필 수 있을 것이 다. 또한 일반인이 가지고 있는 말더듬 관련 지식의 정도가 높을수 록 말더듬에 대한 태도가 긍정적이었다는 선행연구 결과가 있었으 나 이러한 지식의 정도가 연령과 성별에 따른 차이를 보이는지에 대한 연구는 아직 이루어지지 않았으며, 말더듬 관련 지식의 정도 가 구체적으로 PWS에 대한 고정관념이나 신념과 어느 정도 관련 성이 있는지는 불명확하다. 따라서 말더듬 관련 지식을 측정할 수 있는 ASK와 POSHA-S의 네 개 구성요소 및 하위범주 점수와의 상 관분석을 통하여 이러한 관련성을 살필 수 있을 것이다. 구체적인 연구문제는 다음과 같다.

1. 연령과 성별에 따라 POSHA-S의 하위범주인 'PWS에 대한 신 념' 점수와 그 하위 구성요소인 '특성/성격, '도움의 출처', '말 더듬의 원인', '잠재력' 점수에 각각 차이가 있는가?

2. 연령과 성별에 따라 ASK 점수에 차이가 있는가? 
3. POSHA-S의 하위범주인 'PWS에 대한 신념' 점수와 그 하위 구성요소인 '특성/성격', '도움의 출처', '말더듬의 원인', '잠재 력' 점수와 ASK 점수 간 상관이 있는가?

\section{연구 방법}

\section{연구대상}

연구대상은 만 20세 이상이며 한국어를 모국어로 사용하는 일 반 성인 남녀였다. 모든 대상자는 연구의 목적과 내용을 듣고 연구 에 동의하여 자발적으로 참여하였으며, 연구를 실시하기 전 대상 자 선별 질문지를 작성하였다. 선별 질문지를 통한 본인 보고에 의 해 (1) 언어병리학 전공자가 아니고 유창성장애 관련 전공지식을 습득한 적이 없으며, (2) 시력이나 청력에 문제가 없고, (3) 읽기 이해 에 문제가 없다고 답한 사람들의 자료를 본 연구에 사용하였다. 본 연구는 PWS에 대한 일반인의 고정관념과 지식을 살피는 것을 목 적으로 하고 있으므로 POSHA-S에서 PWS를 아는 정도, 즉, PWS 와의 친숙성을 측정하는 문항에 자기 자신을 PWS라고 답한 대상 자의 경우 분석에서 제외하였다. 따라서 POSHA-S에 응답한 총 332 명의 자료 중 성별을 기입하지 않은 자료(8명), 자신을 PWS라 답한 자료(2명), 문항에 불성실하게 응답한 자료(24명)를 제외한 298 명의 자료를 연구에 사용하였다. 대상자의 $69.46 \%$ 인 207 명은 Chon (2016)의 연구에도 참여하였다. POSHA-S는 25-50명 정도의 표본크기를 통해서도 신뢰할 수 있는 결과를 얻을 수 있다는 선행 연구를 근거로 하여(St. Louis, 2012a) 연령집단별 대상자의 수는 50 명 이상이었으며, 각 연령집단 내 남성집단과 여성집단 모두 최소
25 명 이상이 되도록 하였다. 연령과 성별집단 간 표본크기에 차이 가 있는지 확인하기 위하여 실시한 카이제곱 검정 결과 유의한 차 이가 없는 것으로 나타났다 $\left(\chi_{(3)}^{2}=2.671, p>.05\right)$. 각 연령집단과 성 별집단의 기술통계 결과는 Table 1 에 제시하였다.

또한 POSHA-S에서 수집하는 기본정보를 사용하여 연령과 성 별에 따른 교육 연수와 경제적 수준을 비교하기 위해 이원분산분 석을 각각 실시하였다. 교육 연수는 응답자의 최종학력을 기준으로 측정하였으며, 경제적 수준은 가족의 연 소득에 대한 응답을 기반 으로 하여 분석이 이루어졌다. 그 결과, 교육 연수의 경우 연령과 성 별 간 상호작용효과와 성별에 따른 주효과는 유의하지 않았지만 연 령에 따른 주효과가 유의한 것으로 나타났다 $\left(F_{(3,290)}=6.82, p<.001\right)$. Tukey HSD 사후검정 결과, 30 대 집단이 20 대 집단 $(p<.01)$ 과 50 대 이상 집단 $(p<.01)$ 보다 평균 교육 연수가 유의하게 높았으며, 40 대 집단이 50 대 이상 집단보다 평균 교육 연수가 유의하게 높은 것으 로 나타났다 $(p<.05)$. 경제적 수준의 경우, 상호작용효과와 주효과 모두 유의하지 않은 것으로 나타났다.

\section{연구절차}

\section{검사도구}

PWS에 대한 일반인의 고정관념과 신념을 살피기 위해 POSHAS (St. Louis, 2012a)의 한국어 번역본을 사용하였다(Chon, 2016). POSHA-S의 하위범주인 'PWS에 대한 신념'은 총 16 개 문항으로 이루어져 있다. 모든 문항은 서술문의 형태로 되어 있으며, 대상자 가 각각의 내용을 읽고 자신의 생각을 '그렇다/아니다/잘 모르겠음' 으로 답하게 된다.

Table 1. Participants' characteristics

\begin{tabular}{|c|c|c|c|c|c|}
\hline Age group (yr) & Sex & No. of participants (\%) & Age (yr) & Education (yr) & Income rating $^{\mathrm{a}}$ \\
\hline $20 s(20-29)$ & $\begin{array}{l}\text { Male } \\
\text { Female } \\
\text { Total }\end{array}$ & $\begin{array}{c}60(55.6) \\
48(44.4) \\
108(100)\end{array}$ & $\begin{array}{l}24.72 \pm 2.48 \\
22.75 \pm 2.21 \\
23.85 \pm 2.55\end{array}$ & $\begin{array}{l}14.27 \pm 1.93 \\
14.50 \pm 2.00 \\
14.37 \pm 1.96\end{array}$ & $\begin{array}{l}-3.08 \pm 27.87 \\
-3.33 \pm 27.32 \\
-3.19 \pm 27.50\end{array}$ \\
\hline $30 s(30-39)$ & $\begin{array}{l}\text { Male } \\
\text { Female } \\
\text { Total }\end{array}$ & $\begin{array}{l}35(53.8) \\
30(46.2) \\
65(100)\end{array}$ & $\begin{array}{l}34.76 \pm 2.71 \\
33.64 \pm 2.77 \\
34.24 \pm 2.78\end{array}$ & $\begin{array}{l}15.89 \pm 1.18 \\
15.33 \pm 2.48 \\
15.63 \pm 1.90\end{array}$ & $\begin{array}{l}4.84 \pm 32.97 \\
1.42 \pm 38.24 \\
3.35 \pm 35.07\end{array}$ \\
\hline $40 s(40-49)$ & $\begin{array}{l}\text { Male } \\
\text { Female } \\
\text { Total }\end{array}$ & $\begin{array}{l}26(44.1) \\
33(55.9) \\
59(100)\end{array}$ & $\begin{array}{l}44.68 \pm 2.80 \\
45.00 \pm 2.91 \\
44.86 \pm 2.84\end{array}$ & $\begin{array}{l}15.81 \pm 2.37 \\
14.97 \pm 2.64 \\
15.34 \pm 2.54\end{array}$ & $\begin{array}{l}7.36 \pm 38.41 \\
3.19 \pm 29.71 \\
5.05 \pm 33.61\end{array}$ \\
\hline Over 50s (>50) & $\begin{array}{l}\text { Male } \\
\text { Female } \\
\text { Total }\end{array}$ & $\begin{array}{l}31(47.0) \\
35(53.0) \\
66(100)\end{array}$ & $\begin{array}{l}54.48 \pm 3.80 \\
53.85 \pm 3.37 \\
54.14 \pm 3.56\end{array}$ & $\begin{array}{l}14.26 \pm 2.72 \\
14.00 \pm 3.21 \\
14.12 \pm 2.97\end{array}$ & $\begin{array}{r}-.30 \pm 33.79 \\
-5.03 \pm 37.74 \\
-2.78 \pm 35.70\end{array}$ \\
\hline Total & $\begin{array}{l}\text { Male } \\
\text { Female } \\
\text { Total }\end{array}$ & $\begin{array}{l}152(51.0) \\
146(49.0) \\
298(100)\end{array}$ & $\begin{array}{l}36.52 \pm 11.91 \\
37.47 \pm 12.65 \\
36.99 \pm 12.27\end{array}$ & $\begin{array}{l}14.90 \pm 2.19 \\
14.66 \pm 2.59 \\
14.78 \pm 2.39\end{array}$ & $\begin{array}{r}.96 \pm 32.11 \\
-1.42 \pm 32.46 \\
-.19 \pm 32.24\end{array}$ \\
\hline
\end{tabular}

Values are presented as number $(\%)$ or mean \pm SD.

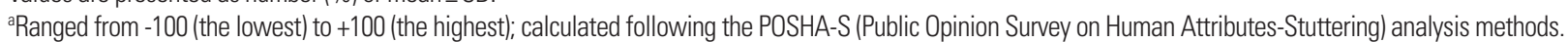


각 구성요소별 문항의 수를 살펴보면 ‘특성/성격'은 3개 문항으 로 이루어져 있으며 PWS가 어떠한 성격이나 특성을 가지고 있는지 알아보고 있다(예: PWS는 신경질적이거나 흥분을 잘한다, PWS는 수줍어하거나 두려워한다). ‘도움의 출처'도 3개 문항으로 이루어져 있으며 말더듬 문제가 누구의 도움을 받아야 한다고 생각하는지 답하게 되어 있다(예: 다른 PWS, 언어재활사), '말더듬의 원인'은 6 개 문항으로 구성되어 있으며 응답자가 무엇이 말더듬의 원인이라 고 생각하는지 답하게 한다(예: 유전적 영향, 매우 무서운 사건, 불 가항력, 학습이나 습관, 바이러스나 질병 등). 마지막으로 '잠재력' 은 4개 문항으로 구성되어 있으며 각 문항을 읽고 PWS에게 가능하 다고 생각하는지 여부를 답하게 되어 있다(예: PWS는 그들이 원하 는 어떠한 직업도 가질 수 있다, PWS는 친구를 사귈 수 있다).

ASK는 말더듬과 관련된 26문항의 서술문으로 이루어져 있으며, 각 문항을 읽고 그 내용이 맞는지 틀린지(true/false) 답하게 되어있 다(Crowe \& Cooper, 1977). 각 문항은 말더듬 문헌에 기술되어 있 는 말더듬의 원인(예: 많은 경우 말더듬의 원인은 유년기 시절의 특 정 사건 때문일 수 있다, 말더듬은 가계력이 있는 것으로 보인다), 말더듬/PWS의 특징(예: 말더듬는 사람들은 자신이 더듬을 단어를 자주 예측할 수 있다, 인구 중 대략 5\%는 살면서 언젠가 말을 더듬 을 것이다, 말더듬는 사람의 5 명 중 무려 4 명이 아무런 도움 없이 말 더듬에서 회복되는 것으로 나타났다), 말더듬 치료와 관련된 내용 (예: 단조로운 리듬으로 말하는 것은 일반적으로 말더듬는 사람이 더욱 유창하게 말할 수 있도록 도울 것이다)으로 구성되어 있으며, 문헌의 내용을 기준으로 정답이 정해져 있다. 하지만 이 검사는 1977년에 제작되었기 때문에 내용이 명확하지 않거나 정답이 최근 의 연구 결과와 일치하지 않는 문항이 3 개(4번, 6 번, 25 번) 있었다. 4 번 문항은 “사실상 말더듬은 일반적으로 갑작스럽게 시작된다"이 며(Crowe \& Cooper, 1977, p. 355), 정답이 틀린 것으로 되어 있다. 이 문항은 1970 년대 당시 학습 행동의 관점에서 말더듬 시작의 특 성과 관련된 응답자의 지식을 확인하기 위해 만든 것으로 보인다. 하지만 최근의 국내외 연구들은 말더듬의 시작이 점진적일 수도 있 고 갑작스러울 수도 있으며, 점진적인 경우보다 갑자기 시작되는 경 우의 비율이 약 1.5-2배 가량 높다고 보고하고 있다(Shin, 2011; Yairi \& Ambrose, 2005). 예를 들어, Yairi와 Ambrose (2005)는 말더듬 이 하루 혹은 2-3일 내로 갑작스럽게 시작되었다고 보고한 아동의 비율이 $40.7 \%$ 였으며, 말더듬이 3 주 이상의 기간을 두고 점진적으 로 시작되었다고 보고한 아동의 비율이 27.1\%였다고 하였다. 국내 말더듬 아동을 대상으로 이루어진 Shin (2011)의 연구에서도 말더 듬이 갑자기 시작되었다고 보고한 비율이 $67 \%$ 로 점진적으로 시작 되었다고 보고한 비율(33\%)보다 2배 이상 높게 나타났다. 따라서
이 문항은 최근의 관점 및 연구 결과와 상반되기 때문에 본 연구에 서 제외하였다. 6 번 문항은 "대부분의 말더듬 순간들은(단어를 끝 마치기 위해 걸리는 시간) 지속시간이 2초 미만이다”이며(Crowe \& Cooper, 1977, p. 356) 정답이 맞는 것으로 되어있다. 하지만 이 문항 은 말더듬 중증도나 말더듬 행동 특성에 따라, 혹은 발화 환경이나 상황에 따라 다양하게 나타나는 말더듬 순간의 지속시간을 지나치 게 단순화시켜 기술하였으며 이를 맞다고 하였기 때문에 연구에서 제외하였다. 마지막으로 25번 문항은 "말더듬는 사람들은 어느 연 령에서든 말더듬이 회복될 수도 있다”(Crowe \& Cooper, 1977, p. 357)이며 정답이 맞는 것으로 되어있다. 이 문항의 경우 회복(recover)이라는 용어가 모호하다고 판단하였다. 회복이 자연회복을 의미하는 것이라면 말더듬 시작 이후 5 년 이내에 최대 $79 \%$ 정도까 지는 자연회복이 이루어지지만 그 이후에는 자연회복의 가능성이 매우 낮기 때문이다(Yairi \& Ambrose, 2005). 반면 회복이 치료를 통한 회복이라면 어느 연령에서든 일어날 수 있을 것이다. 따라서 회복이라는 용어의 구체적인 의미에 따라 답이 바뀔 수 있으므로 이 문항 역시 연구에서 제외하였다. 따라서 26 개의 문항 중 3 개 문 항을 제외한 23 개의 문항을 본 연구에 사용하였다.

영어로 되어있는 ASK 검사지는 번역-역번역 절차를 거쳤다. 언어 재활사 2 급 자격증을 소지하고 있으며 대학원 석사과정에서 언어 병리학을 전공하고 말더듬 관련 학위논문을 쓰는 학생이 일차적 으로 검사지를 한국어로 번역하였고, 본 연구의 저자가 번역 내용 에 왜곡 혹은 오역이 있는지 여부를 원 검사지와 비교 확인한 후 의 미상 어색한 부분을 수정하였다. 그 다음 단계로 한국어-영어 이중 언어 사용자가 한국어로 번역한 내용을 다시 영어로 역번역하였다. 그 후 본 연구의 저자가 검사지 원본의 내용과 역번역한 내용이 의 미상 일치하는지 확인하는 절차를 거쳤다. 한국어로 번역한 ASK는 언어재활사 2 급 자격증을 소지하고 있으며 말더듬 평가 및 치료 경 력이 3 년 이상인 언어재활사 3 명으로부터 내용타당도 검증절차를 거쳤다(Ko, 2015).

\section{자료수집}

본 연구의 저자와 언어재활사 2 급 자격증을 소지하고 있는 언어 병리학 석사과정 학생 세 명이 자료를 수집하였다. 연구의 저자는 학생들을 대상으로 본 연구의 목적 및 설문도구인 POSHA-S 작성 방법, ASK 작성방법에 대해 설명하여 학생들이 연구에 대해 정확 히 이해한 후 자료수집이 이루어지도록 하였다.

자료수집은 서울경기 지역과 광주전남 지역에 거주하는 만 20세 이상 불특정 성인을 대상으로 이루어졌다. 연구는 연구대상자가 본 연구의 목적, POSHA-S 및 ASK 작성방법, 연구 소요시간 등에 
대한 설명이 적혀있는 실험패킷의 첫 페이지를 읽고 연구참여에 대 한 동의를 하는 경우 자발적으로 참여하는 방식으로 이루어졌다. 연구대상자는 먼저 실험패킷에 제시된 대상자 선별 질문지에 답한 후 POSHA-S의 'PWS에 대한 신념' 하위범주에 속하는 문항과 ASK 의 문항에 답하였다.

\section{자료분석}

PWS에 대한 일반인의 고정관념과 신념을 살피기 위해 POSHA$\mathrm{S}$ 의 'PWS에 대한 신념' 하위범주에 속하는 문항들을 분석하였다. 전술하였듯이 'PWS에 대한 신념' 하위범주는 총 16 개 문항으로 구 성되어 있으며 각 문항은 응답자가 자신의 생각을 '그렇다/아니다/ 잘 모르겠음으로 답하게 되어있다. 따라서 St. Louis (2012a, 2012b) 에서 제시한대로 각 문항의 응답을 아니다 $=1$, 잘 모르겠음 $=2$, 그 렇다 $=3$ 으로 우선 변환한 후, $1=-100$ 점, $2=0$ 점, $3=+100$ 점의 등 간척도로 변환하였다. 총 문항의 약 $56 \%$ 인 9 개의 문항은 역변환 하 여 분석해야 했으므로(예: PWS는 수줍어하거나 두려워한다), 그렇 다 $=1$, 잘 모르겠음 $=2$, 아니다 $=3$ 으로 우선 변환한 후에 점수로 변환하였다.

변환된 각 문항의 점수는 4 개의 구성요소, 즉, '특성/성격', '도움 의 출처', '말더듬의 원인', '잠재력' 점수를 산출하기 위해 사용되었 다. 즉, 각 구성요소에 포함되어 있는 문항들의 평균점수를 계산하 여 각각의 구성요소 점수를 산출하였다. 마지막으로 'PWS에 대한 신념' 점수를 얻기 위해 4개 구성요소 점수의 평균을 계산하였다.

POSHA-S는 -100 점이 최저점이며 +100 점이 최고점이 된다. 각 문항에서 - 100 점은 PWS에 대한 의견이 부정적임을 의미하며, +100 점은 반대로 PWS에 대한 의견이 긍정적임을 의미한다. 0 점은 중간 점수로 응답자의 의견이 중립적이거나 확실치 않음을 의미한다. 따 라서 각 구성요소의 점수와 'PWS에 대한 신념' 점수가 최저점에 가 까워질수록 응답자의 의견이 부정적이거나 PWS에 대한 부정적인 고정관념이나 신념이 심하다는 것을 의미하며, 최고점에 가까워질 수록 응답자의 의견이 긍정적이거나 PWS에 대한 긍정적인 고정관 념이나 신념을 갖고 있음을 의미한다.
ASK는 연구대상자 298명 중 검사에 불성실하게 답변한 9명(남 5 명, 여 4 명)의 자료를 제외하고 289 명의 자료를 분석하였다. 각 문항 에 대한 응답자의 답변이 정답과 일치할 경우 1 점씩 부여하였으며, 정답의 개수가 최종 점수가 되었다. 대상자가 응답하지 않은 문항 은 틀린 것으로 채점하였다(Crowe \& Cooper, 1977). ASK는 점수 가 높을수록 말더듬에 대한 지식이 높음을 의미한다. 전술한대로 본 연구에서는 총 26 개 문항 중 23 개를 사용하였으므로 최저점은 0점이며 최고점은 23점이었다.

\section{자료의 통계적 처리}

각 연구문제별로 자료의 통계적 처리는 IBM SPSS Statistics ver. 21을 사용하여 다음과 같이 실시하였다:

PWS에 대한 신념을 통계적으로 분석하기 위해 연령(4개 집단) 과 성별(2개 집단) 두 개의 요인을 독립변수로 설정하였으며, 구성 요소인 '특성/성격', '도움의 출처', '말더듬의 원인', '잠재력' 점수와 최종점수인 'PWS에 대한 신념' 점수를 종속변수로 설정하였다. 앞 서 설명하였듯이 POSHA-S에는 PWS와의 친숙성을 측정하는 문 항이 있다. 이 문항은 응답자에게 PWS를 전혀 알지 못하는지, 아니 면 지인, 친한 친구, 친족, 자기 자신, 그 외 다른 사람 중 말을 더듬 는 사람이 있는지 묻고 응답자의 답변(중복 답변 가능)을 POSHA$\mathrm{S}$ 의 점수변환 체계를 사용하여 -100 점부터 +100 점으로 환산한다. 따라서 PWS를 많이 알고 있을수록, 즉, 친숙성이 높을수록 +100 점에 가까워진다. 본 연구에서는 이 문항의 점수와 교육 연수를 잠 재적인 가외변수로 설정하였다. 통계처리 방법을 결정하기 위하여 잠재적인 가외변수와 종속변수 간 피어슨 적률상관계수(Pearson's product moment correlation coefficient)를 사용한 상관분석을 실 시한 결과, 교육 연수와 친숙성 점수는 각 종속변수와 상관계수의 절대값이 .1 미만으로 상관의 정도가 거의 없는 것으로 나타났다

(Table 2).

각 종속변수 간 상관분석을 실시한 결과 역시 Table 2에 제시하 였다. 모든 구성요소의 점수는 하위범주 점수인 'PWS에 대한 신 념' 점수와 대부분 비교적 높은 정적상관이 있는 것으로 나타났다

Table 2. Pearson's product moment correlation coefficients between variables

\begin{tabular}{lcccccc}
\hline & Familiarity & Traits/personality & Help source & Cause & Potential & Beliefs about people who stutter \\
\hline Years of education & .028 & -.046 & -.035 & -.074 & .009 & -.064 \\
Familiarity & - & .023 & .044 & .043 & .065 & .079 \\
Traits/personality & & - & -.017 & $.116^{*}$ & $.153^{* *}$ & $.685^{* * *}$ \\
Help source & & & - & .020 & -.046 & $.376^{* * *}$ \\
Cause & & & & - & .008 & $.473^{* * *}$ \\
Potential & & & & - & $.557^{* * *}$ \\
\hline
\end{tabular}

${ }^{*} p<.05,{ }^{* *} p<.01,{ }^{* * *} p<.001$. 
( $p<.01)$. 이는 'PWS에 대한 신념' 점수가 구성요소 점수의 평균이 기 때문인 것으로 보인다. 각 구성요소 종속변수 간 상관분석 결과, 상관계수의 절대값이 .2 미만으로 상관의 정도가 거의 무시할 만한 수준인 것으로 나타났다(Sung \& Si, 2014). '특성/성격’은 ‘말더듬의 원인'과 '잠재력' 간 상관분석 결과가 통계적으로 유의하기는 하였 으나, 실제 상관의 정도는 통계결과의 유의미성이 아니라 상관계수 값을 기준으로 해석하게 되므로(Kim, 2013) 이 결과는 상관의 정 도가 매우 낮은 것으로 판단하였다. 또한 본 연구는 일반인이 연령 과 성별에 따라 PWS에 대해 보이는 고정관념을 명확히 파악하기 위하여 각 구성요소의 특성을 구체적으로 살피고자 하였기 때문 에 각 종속변수별로 이원분산분석(two-way Analysis of Variance) 을 실시하였다. 이원분산분석 결과 유의한 주효과가 나타난 경우 Tukey 사후검정을 실시하였다.

연령과 성별에 따라 말더듬 관련 지식에 차이가 있는지 살피기 위하여 연구문제 1 번과 마찬가지로 연령과 성별 두 개의 요인을 독 립변수로 설정하였으며, ASK 점수를 종속변수로 설정하였다. 말더 듬 관련 지식 역시 교육 연수와 PWS에 대한 친숙성에 영향을 받을 수 있기 때문에 이 두 변수와 ASK 점수 간 상관분석을 실시한 결 과, 변수 간 상관의 정도가 무시할만한 수준인 것으로 나타났다(교 육 연수와 ASK, $r=.076$; 친숙성과 ASK, $r=-.034)$. 따라서 연령과 성별에 따른 ASK 점수에 차이를 확인하기 위해 이원분산분석을 실시하였다.

POSHA-S의 하위범주인 'PWS에 대한 신념' 점수 및 구성요소 점 수와 말더듬 관련 지식 간 상관성을 살피기 위하여 'PWS에 대한 신

Table 3. Participants' responses on the POSHA-S items

\begin{tabular}{|c|c|c|c|c|}
\hline & Item & Yes & Not sure & No \\
\hline Traits/personality & $\begin{array}{l}\text { Blame* } \\
\text { Nervous* } \\
\text { Shy* }\end{array}$ & $\begin{array}{l}35.9(107) \\
24.5(73) \\
64.8(193)\end{array}$ & $\begin{array}{l}18.1(54) \\
11.1(33) \\
10.1(30)\end{array}$ & $\begin{array}{l}46.0(137) \\
64.4(192) \\
25.2(75)\end{array}$ \\
\hline Help source & $\begin{array}{l}\text { SLP } \\
\text { Stutterers } \\
\text { Doctor }^{*}\end{array}$ & $\begin{array}{l}94.6(282) \\
28.2(84) \\
76.2(227)\end{array}$ & $\begin{array}{l}1.3(4) \\
6.7(20) \\
2.7(8)\end{array}$ & $\begin{array}{c}4.0(12) \\
65.1(194) \\
21.1(63)\end{array}$ \\
\hline Cause & $\begin{array}{l}\text { Genetic } \\
\text { Learning* } \\
\text { Fright* } \\
\text { Act of god* } \\
\text { Virus/disease* } \\
\text { Ghost/demon* }\end{array}$ & $\begin{array}{c}55.4(165) \\
63.4(189) \\
53.7(160) \\
38.9(116) \\
36.6(109) \\
5.0(15)\end{array}$ & $\begin{array}{r}8.1(24) \\
5.7(17) \\
10.4(31) \\
12.1(36) \\
8.1(24) \\
6.4(19)\end{array}$ & $\begin{array}{l}36.6(109) \\
30.9(92) \\
35.9(107) \\
49.0(146) \\
55.4(165) \\
88.6(264)\end{array}$ \\
\hline Potential & $\begin{array}{l}\text { Friends } \\
\text { Normal life } \\
\text { Any job } \\
\text { Judgment job }\end{array}$ & $\begin{array}{l}88.9(265) \\
82.9(247) \\
59.4(177) \\
54.0(161)\end{array}$ & $\begin{array}{r}3.4(10) \\
4.7(14) \\
9.7(29) \\
13.4(40)\end{array}$ & $\begin{array}{r}7.7(23) \\
12.4(37) \\
30.9(92) \\
32.6(97)\end{array}$ \\
\hline
\end{tabular}

Values are presented as percent (number of responses).

POSHA-S=Public Opinion Survey on Human Attributes-Stuttering; SLP= speechlanguage pathologist.

*Items were reverse scored following the POSHA-S analysis methods.
념, '특성/성격, ‘도움의 출처', '말더듬의 원인' '잠재력' 점수와 ASK 점수간 피어슨 적률상관계수를 사용한 상관분석을 실시하였다.

\section{연구 결과}

POSHA-S의 각 문항에 대해 전체 대상자가 응답한 비율을 정리 한 내용은 Table 3에 제시하였다. '특성/성격'의 경우 $64.8 \%$ 의 응답 자가 PWS가 수줍음이 있거나 두려움이 있다고 생각하는 것으로 나타났다. '도움의 출처'는 언어재활사에게 도움을 받아야 한다는 응답이 $94.6 \%$ 였으나 의사의 도움을 받아야 한다는 응답도 $76.2 \%$ 로 높게 나타났다. 반면 다른 PWS에게 도움을 받아야 한다는 문항 에 동의하지 않은 비율이 $65.1 \%$ 로 높게 나타났다. '말더듬의 원인'과 관련된 문항에서 응답자의 $55.4 \%$ 가 말더듬의 원인이 유전적이라는 것에 동의하였으나, 말더듬이 학습이나 습관 때문이라고 생각하거 나 정서적 경험(매우 무서운 사건) 때문이라고 생각하는 응답자의 비율도 각각 $63.4 \%$ 와 $53.7 \%$ 로 높게 나타났다. '잠재력'의 경우, 대다 수의 응답자가 PWS가 친구를 사귀거나 평범한 삶을 살 수 있다고 응답하였으나 직업적인 측면에서는 부정적인 응답이 상승한 것으

Table 4. Descriptive statistics of dependent variables (POSHA-S) according to age and sex

\begin{tabular}{|c|c|c|c|c|}
\hline & $\begin{array}{c}\text { Age group } \\
\text { (yr) }\end{array}$ & Male & Female & Total \\
\hline Traits/personality & $\begin{array}{l}20 \mathrm{~s} \\
30 \mathrm{~s} \\
40 \mathrm{~s} \\
\text { Over 50s } \\
\text { Total }\end{array}$ & $\begin{array}{l}6.15 \pm 59.55 \\
1.91 \pm 52.89 \\
3.85 \pm 50.91 \\
3.23 \pm 52.48 \\
4.18 \pm 54.72\end{array}$ & $\begin{array}{r}7.58 \pm 49.09 \\
-7.77 \pm 55.72 \\
4.06 \pm 49.68 \\
3.80 \pm 56.98 \\
2.73 \pm 52.34\end{array}$ & $\begin{array}{r}6.79 \pm 54.90 \\
-2.55 \pm 54.01 \\
3.97 \pm 49.79 \\
3.53 \pm 54.49 \\
3.47 \pm 53.48\end{array}$ \\
\hline Help source & $\begin{array}{l}20 \mathrm{~s} \\
30 \mathrm{~s} \\
40 \mathrm{~s} \\
\text { Over 50s } \\
\text { Total }\end{array}$ & $\begin{array}{r}-8.25 \pm 42.16 \\
4.77 \pm 39.47 \\
0.00 \pm 32.33 \\
12.81 \pm 34.88 \\
.45 \pm 39.06\end{array}$ & $\begin{array}{r}-10.96 \pm 32.27 \\
0.03 \pm 33.63 \\
4.06 \pm 40.36 \\
5.69 \pm 36.30 \\
-1.32 \pm 35.80\end{array}$ & $\begin{array}{r}-9.45 \pm 37.94 \\
2.58 \pm 36.68 \\
2.27 \pm 36.79 \\
9.03 \pm 35.55 \\
-.41 \pm 37.45\end{array}$ \\
\hline Cause & $\begin{array}{l}20 s \\
30 s \\
40 s \\
\text { Over 50s } \\
\text { Total }\end{array}$ & $\begin{array}{r}12.77 \pm 35.48 \\
15.69 \pm 40.79 \\
15.96 \pm 22.71 \\
9.74 \pm 41.67 \\
13.37 \pm 36.09\end{array}$ & $\begin{array}{r}12.48 \pm 34.56 \\
8.37 \pm 34.87 \\
24.21 \pm 43.32 \\
9.51 \pm 39.21 \\
13.58 \pm 37.96\end{array}$ & $\begin{array}{r}12.64 \pm 34.91 \\
12.31 \pm 38.06 \\
20.58 \pm 35.70 \\
9.62 \pm 40.07 \\
13.47 \pm 36.95\end{array}$ \\
\hline Potential & $\begin{array}{l}20 s \\
30 s \\
40 s \\
\text { Over 50s } \\
\text { Total }\end{array}$ & $\begin{array}{l}50.00 \pm 44.63 \\
48.57 \pm 36.35 \\
49.04 \pm 46.63 \\
41.13 \pm 47.24 \\
47.70 \pm 43.48\end{array}$ & $\begin{array}{l}60.42 \pm 41.84 \\
36.67 \pm 52.82 \\
63.64 \pm 40.06 \\
47.86 \pm 54.70 \\
53.25 \pm 47.82\end{array}$ & $\begin{array}{l}54.63 \pm 43.52 \\
43.08 \pm 44.74 \\
57.20 \pm 43.31 \\
44.70 \pm 51.05 \\
50.42 \pm 45.66\end{array}$ \\
\hline $\begin{array}{l}\text { Beliefs about } \\
\text { people who } \\
\text { stutter }\end{array}$ & $\begin{array}{l}20 s \\
30 s \\
40 s \\
\text { Over 50s } \\
\text { Total }\end{array}$ & $\begin{array}{l}15.13 \pm 25.54 \\
17.74 \pm 25.33 \\
17.31 \pm 19.80 \\
16.71 \pm 23.81 \\
16.43 \pm 24.04\end{array}$ & $\begin{array}{r}17.31 \pm 22.97 \\
9.30 \pm 19.37 \\
24.00 \pm 23.42 \\
16.69 \pm 24.41 \\
17.03 \pm 23.03\end{array}$ & $\begin{array}{l}16.10 \pm 24.34 \\
13.85 \pm 23.00 \\
21.05 \pm 21.97 \\
16.70 \pm 23.94 \\
16.72 \pm 23.51\end{array}$ \\
\hline
\end{tabular}

Values are presented as mean \pm SD.

POSHA-S = Public Opinion Survey on Human Attributes-Stuttering. 
로 나타났다. 각 구성요소 내의 몇몇 문항을 통해 일반인이 PWS에 대해 부정적인 고정관념과 신념을 보이고 있음을 알수 있었다.

\section{연령과 성별에 따른 고정관념 비교 결과: POSHA-S}

연령과 성별에 따라 각 구성요소 점수의 평균과 표준편차를 산 출한 결과는 Table 4에 제시하였다. '특성/성격'은 30대 여성집단을 제외한 모든 연령 및 성별집단의 평균점수가 양수(+)로 나타났다. 하지만 전체 평균값이 3.47로 대상자들이 중립에 가까운 의견을 보 인 것으로 나타났다. ‘도움의 출처'는 20대 집단이 성별에 상관없이 평균점수가 음수(-)였으며, 다른 연령대에 비해 낮은 점수를 보였다. 또한 50대 이상 집단의 평균점수가 다른 연령대에 비해 높은 것으 로 나타났다. '말더듬의 원인'의 경우, 모든 집단의 평균점수가 양수 (+)였으며, 40 대 여성집단의 평균점수가 다른 집단에 비해 상대적 으로 높게 나타났다. 마지막으로 '잠재력' 구성요소는 연령과 성별 에 관계 없이 모든 집단의 평균점수가 양수(+)였으며, 다른 구성요 소들보다 높은 평균점수를 보였다.

연령과 성별 간 구성요소의 평균점수에 차이가 있는지 확인하기 위해 이원분산분석을 각각 실시한 결과는 Table 5 에 제시하였다. '특성/성격', '말더듬의 원인', '잠재력'의 경우, 두 요인 간 상호작용 효과가 유의하지 않았으며, 연령 및 성별의 주효과 또한 유의하지 않은 것으로 나타났다. '도움의 출처'는 요인 간 상호작용효과가 유 의하지 않았으며 성별에 따른 주효과 역시 유의하지 않았다. 하지만 연령에 따른 유의한 주효과가 있었다 $\left(F_{(3,290)}=3.876, p<.05\right.$, partial $\eta^{2}=.039$ ). 사후검정 결과, 50 대 이상 집단이 20대 집단보다 '도움의 출처' 구성요소의 평균점수가 유의하게 높은 것으로 나타났다 $(p<.01)$.

'PWS에 대한 신념'의 기술통계 결과 역시 Table 4에 제시하였다. 전체적인 기술통계 결과를 살펴보면 연령과 성별에 상관 없이 평균 점수가 모두 양수였으며, 표준편차가 구성요소들에 비해 크지 않 은 것으로 나타났다. 연령 요인의 경우 30 대 집단이 상대적으로 낮 은 평균점수를 보였으며, 이는 30대 집단 내 여성집단의 평균점수

Table 5. Results of two-way ANOVA for each component

\begin{tabular}{lccccc}
\hline & & \multicolumn{4}{c}{ F-values } \\
\cline { 3 - 6 } & $d f$ & $\begin{array}{c}\text { Traits/ } \\
\text { personality }\end{array}$ & $\begin{array}{c}\text { Help } \\
\text { source }\end{array}$ & Cause & Potential \\
\hline Age & 3 & .445 & $3.876^{*}$ & .900 & 1.727 \\
Sex & 1 & .083 & .350 & .001 & .831 \\
Age $\times$ Sex & 3 & .163 & .255 & .449 & 1.090 \\
Errors & 290 & & & & \\
\hline
\end{tabular}

${ }^{*} p<.05$.
가 다른 연령대 및 성별에 비해 낮았기 때문으로 보인다. 반면 평균 점수가 상대적으로 가장 높았던 집단은 40 대 여성집단이었으며 이 로 인해 40 대 집단의 평균점수가 다른 연령대에 비해 높은 것으로 나타났다. 하지만 이원분산분석 결과, 요인 간 상호작용뿐 아니라 $\left(F_{(3,290)}=1.158, p>.05\right)$ 각 요인의 주효과 역시 유의하지 않았다(연 령: $F_{(3,290)}=.953, p>.05$, 성별: $\left.F_{(1,290)}=.001, p>.05\right)$.

\section{연령과 성별에 따른 말더듬 관련 지식 비교 결과: ASK}

ASK 점수의 기술통계 결과는 Table 6에 제시하였다. ASK 평균점 수는 연령과 성별에 따른 차이가 적게 나타났다. 50대 이상 집단의 점수가 다른 연령집단에 비해 평균점수가 약간 낮았으며 표준편차 값을 통한 변동성 또한 상대적으로 크게 나타났다. 이원분산분석 결과, 연령과 성별 요인 간 상호작용효과가 유의하지 않았으며 $\left(F_{(3,}\right.$ $\left.{ }_{281)}=.268, p>.05\right)$, 연령의 주효과 $\left(F_{(3,281)}=2.035, p>.05\right)$ 와 성별의 주효과 $\left(F_{(1,281)}=.064, p>.05\right)$ 역시 유의하지 않은 것으로 나타났다.

\section{PWS에 대한 고정관념과 말더듬 관련 지식 간 상관}

'PWS에 대한 신념' 점수 및 그 하위 구성요소와 말더듬 관련 지 식을 측정한 ASK 점수의 상관분석을 실시한 결과는 Table 7에 제 시하였다. ASK 점수는 '말더듬의 원인'과 유의한 정적상관이 있었 으며 $(r=.205, p<.001)$, '잠재력' 점수와도 유의한 정적상관이 있었 다 $(r=.178, p<.01)$. 하지만 상관의 정도를 살펴봤을 때 모든 변수 간 상관은 무시할 수준이거나 낮은 것으로 나타났다.

Table 6. Descriptive statistics of ASK according to age and sex

\begin{tabular}{lccc}
\hline Age group (yr) & Male & Female & Total \\
\hline $20 \mathrm{~s}$ & $13.05 \pm 2.62$ & $12.85 \pm 2.26$ & $12.96 \pm 2.46$ \\
$30 \mathrm{~s}$ & $12.97 \pm 2.66$ & $12.52 \pm 1.92$ & $12.75 \pm 2.33$ \\
$40 \mathrm{~s}$ & $12.52 \pm 1.81$ & $12.59 \pm 1.93$ & $12.56 \pm 1.86$ \\
Over 50s & $11.87 \pm 3.16$ & $12.15 \pm 2.73$ & $12.02 \pm 2.92$ \\
Total & $12.69 \pm 2.65$ & $12.56 \pm 2.24$ & $12.63 \pm 2.46$ \\
\hline
\end{tabular}

Values are presented as mean \pm SD.

ASK=Alabama Stuttering Knowledge test.

Table 7. Pearson's product moment correlation coefficients between ASK and POSHA-S variables

\begin{tabular}{cccccc}
\hline & $\begin{array}{c}\text { Traits/per- } \\
\text { sonality }\end{array}$ & $\begin{array}{c}\text { Help } \\
\text { source }\end{array}$ & Cause & Potential & $\begin{array}{c}\text { Beliefs about } \\
\text { people who stutter }\end{array}$ \\
\hline ASK & .113 & .034 & $.205^{* * *}$ & $.178^{* *}$ & .043 \\
\hline
\end{tabular}

ASK = Alabama Stuttering Knowledge test; POSHA-S=Public Opinion Survey on Human Attributes-Stuttering. ${ }^{* *} p<.01,{ }^{* * *} p<.001$. 


\section{논의 및 결론}

본 연구는 일반인이 PWS에 대해 가지고 있는 고정관념 및 신념 과 말더듬 관련 지식의 특성을 살피고자 하였다. 이를 위해 두 개 요 인(연령, 성별)을 독립변수로 하여 집단에 따른 차이를 비교하였다. 연구 결과, 'PWS에 대한 신념'의 구성요소인 '특성/성격', '말더듬의 원인', '잠재력'은 연령과 성별 간 유의한 차이가 없었다. '도움의 출 처'는 50대 이상 집단이 20대 집단보다 평균점수가 유의하게 높았 다. 최종점수인 'PWS에 대한 신념' 점수는 연령과 성별 간 유의한 차이가 없었다. ASK 점수 역시 연령과 성별 간 유의한 차이가 나타 나지 않았으며, ASK 점수와 POSHA-S의 'PWS에 대한 신념' 점수 및 각 구성요소와의 상관을 분석한 결과 ASK 점수는 '말더듬의 원 인'과 ‘잠재력' 점수와 유의한 정적상관을 보였으나 그 정도는 매우 낮게 나타났다.

POSHA-S의 하위범주인 'PWS에 대한 신념' 평균점수는 양수였 으나 20점 미만으로 중립에 가까웠다. 하지만 구성요소의 평균점수 인 이 하위범주 점수만 가지고 일반인이 보이는 PWS에 대한 전반 적인 고정관념이나 신념이 중립적이었다고 하기보다는 각 구성요 소에서, 그리고 그 구성요소 내의 각 문항에서 일반인이 보인 긍정 적/부정적 신념을 종합적으로 고려하고 해석해야 할 것이다.

개개인의 응답의 다양성이 존재했지만 '성격/특성'의 경우 평균 점수의 절대값이 8점 이내로 중립적인 측면을 보였다. 하지만 이러 한 결과를 단순히 선행연구 결과와 상반된다고 하기는 어려울 것으 로 보인다. 말더듬 고정관념으로 여겨지는 성격적 측면의 경우, 성격 과 관련된 형용사를 제시하고 동의하는지 답하게 하거나(Woods \&Williams, 1976) 응답자에게 PWS를 생각하면 떠오르는 형용사 를 직접 쓰게 하는 방식(Lass et al., 1989, 1992, 1994; Lee, 2013; Ruscello et al., 1994; Yairi \& Williams, 1970)을 사용하여 대상자의 응 답을 분석했던 경우가 빈번했기 때문이다. 성격과 관련된 문장을 제시하고 응답하게 한 경우에도 각 문장에 대한 응답자의 반응을 조사하여 분석하였다(Lee, 2013). 본 연구에서 이루어진 POSHA-S 의 각 문항의 결과를 살피면 PWS가 “수줍어하거나 두려워한다"는 문항에 동의한, 즉 부정적인 의견을 보인 비율이 전체의 $64.8 \%$ 로 나타났다(Table 3). 이 결과는 선행연구의 결과를 일관되게 지지하 는 것으로(Craig et al., 2003; Hughes, Gabel, Irani, \& Schlagheck, 2010; Lass et al., 1989, 1992, 1994) 국내 일반인도 PWS의 성격/특 성에 부정적인 고정관념이 있음을 알 수 있었다. 하지만 “신경질적 이거나 흥분을 잘 한다”는 문항에 동의했던 비율은 $24.5 \%$ 로 낮았 으며, 이는 PWS의 성격이 신경질적이라는 고정관념을 보고했던 국 외 연구(예: Abdalla \& St. Louis, 2014)와 다소 상반된 모습을 보였
다. 또한 “말더듬을 자신의 탓으로 여긴다”는 문항에도 동의하는 비율이 낮았던 경향으로 인해 세 개 문항의 응답을 평균 내어 산출 하는 구성요소 점수가 0 (중립)에 가까웠던 것으로 보인다. PWS가 수줍음과 두려움이 있다는 일관된 고정관념은 서론에서 언급했듯 이 말을 더듬지 않는 일반인의 경험에서 기인할 것이라는 연구자들 의 주장을 지지한다(Doody et al., 1993; MacKinnon et al., 2007; White \& Collins, 1984). 말더듬이라는 장애에 대해 잘 알지 못하기 때문에 자신이 일시적으로 말을 더듬었을 때의 상황과 그때 자신 의 느낌을 PWS에게 적용해서 판단하려 할 수 있기 때문이다. 혹은 PWS가 자신의 말더듬과 관련한 부정적인 경험이 반복되면서 다른 사람들과 구어 의사소통을 하는 데 소극적이고, 자신의 의사소통 에 대해 걱정하는 모습을 보였기 때문일 수도 있다(Arnold et al., 2015; Blood, Blood, Tellis, \& Gabel, 2001). 이는 서론에서 언급한 자기 낙인, 즉, PWS 스스로가 자신의 말에 대해 청자가 보이는 부 정적인 반응을 받아들여 내재화시킨 것으로도 해석이 가능할 것 이다. 실제 말더듬 청소년은 구어 의사소통 시 두려움과 불안감을 많이 보였으며 스스로 느끼는 의사소통 역량도 일반 청소년에 비해 낮게 나타났다(Blood et al., 2001). 이러한 모습을 일반인은 PWS가 수줍음이 많거나 내향적이거나, 혹은 자신감이 없는 것으로 생각 하고 이를 일반화 시킬 수 있을 것이다. 일반인의 고정관념이 환경 적인 요인으로 작용하여 PWS에게 부정적인 영향을 미치고, 이로 인해 PWS가 구어 의사소통에 부담을 느끼게 되며, 이러한 모습이 다시 일반인의 부정적인 고정관념을 강화시킬 수도 있을 것이다. 또 한 청자가 보이는 PWS의 성격특성에 대한 부정적인 고정관념은 영 화, 드라마, 혹은 코미디 프로그램과 같은 대중매체나 문학작품의 영향을 받았을 가능성이 있다(Bushey \& Martin, 1988; Sim, 2000). 대중매체는 그 특성상 PWS의 말이나 행동을 희화화시키거나 PWS 의 성격을 정형화시켜서 대중에게 전달하는 경우가 발생한다. 많은 문학작품 역시 PWS의 성격을 수줍어하고 소극적인 것으로 묘사 하고 있으며 PWS의 말더듬 행동에 대한 청자의 반응을 부정적으 로 기술하고 있는 경우가 빈번하였다(Bushey \& Martin, 1988). 따 라서 일반인이 이러한 대중매체나 문학작품에 노출되며 자연스럽 게 PWS에 대한 사회적 학습이 이루어졌을 수 있다.

'말더듬의 원인' 평균점수 역시 중립에 가까운 것으로 나타났다. 하지만 본 연구 결과를 통해 주의 깊게 살펴야 할 점은 일반인이 말 더듬의 원인을 학습/습관이나 부정적인 정서적 경험(매우 무서운 사건) 때문이라고 여기는 잘못된 신념을 가지고 있었다는 것이다. 이러한 신념은 일반인이 말더듬을 의사소통장애로 여기기 보다는 습관상의 문제, 혹은 정서적인 문제나 질병으로 잘못 생각할 수 있 음을 시사한다. 또한 이 역시 앞서 논의하였던 기준점과 조정 휴리 
스틱(MacKinnon et al., 2007)을 적용할 수 있을 것이다. 즉, 유창한 일반인이 말을 더듬게 되었던 상황과 말더듬의 발생을 연결시켜 반 응할 수 있는 것으로 보인다. 말더듬은 다양한 원인이 서로 복합적 으로 작용하며(Smith \& Kelly, 1997) 모든 말더듬 문제를 설명할 수 있는 명확한 원인은 아직 밝혀지지 않았다. 따라서 일반인은 자신 의 개인적인 경험을 통해 말더듬의 원인과 관련한 신념을 생성하고 유지하고 있음을 예상해 볼 수 있다. Boyle 등(2009)은 연구에 참여 한 일반 학생들을 집단으로 나누고 말더듬의 원인을 유전적, 심리 적, 원인을 알 수 없음으로 각각 다르게 알려준 후 사회적 거리(social distance)를 측정한 결과 말더듬이 심리적인 원인이라고 알려 준 집단의 사회적 거리가 다른 집단에 비해 유의하게 멀었음을 보 고하였다. 이는 말더듬의 원인과 관련된 잘못된 지식 혹은 신념이 PWS에 대한 부정적인 반응으로 연결될 수 있음을 시사한다.

‘도움의 출처'는 50 대 이상 집단이 20 대 집단보다 더 긍정적인 태 도를 보임을 알 수 있었지만 각 연령대의 평균점수 모두 절대값이 13점 미만으로 중립적인 모습을 보였다. 이 구성요소에 포함된 각 문항의 응답을 연령집단별로 살펴본 결과 언어재활사나 의사의 도 움을 받아야 한다고 응답한 경우는 연령과 상관없이 비슷하였으 며, 언어재활사에게 도움을 받을 수 있다고 응답한 비율은 $94.6 \%$ 로 응답자의 대다수가 긍정적인 반응을 보였다. 하지만 다른 PWS 에게 도움을 받아야 한다고 한 응답은 연령대에 따라 다르게 나타 났다. 20대 집단은 다른 PWS에게 도움을 받을 수 없다고 응답한 비율이 $77.8 \%$ 인 데 반해 50대 이상은 다른 PWS에게서 도움을 받 을 수 있다고 응답한 비율(48.5\%)과 도움을 받을 수 없다고 응답한 비율(47.0\%)이 비슷하게 나타났다. 이러한 결과는 전반적으로 말더 듬이라는 장애를 어떻게 보느냐는 관점의 측면으로 해석할 수 있 을 것이다. '말더듬의 원인' 구성요소에서 일반인은 말더듬의 원인 이 학습/습관 때문이라는 응답과 부정적인 정서적 경험 때문이라 고 응답한 비율이 높았다. 만일 이러한 이유 때문에 말더듬이 발생 한다면 의사의 상담을 받아야 한다고 생각할 수 있을 것이다. 또한 높은 비율은 아니었으나 바이러스/질병이 말더듬의 원인이라고 응 답한 경우도 의사의 진료가 필요하다고 생각할 수 있을 것이다. 반 면 이러한 신념을 가지고 있다면 환자의 입장이 되는 PWS는 서로 에게 도움을 주기 어렵다고 생각할 수 있을 것으로 보이며, 이러한 생각이 20대 집단에서 더 높게 나타났던 것으로 보인다. 또한 말더 듬에 대한 지식이나 정보가 부족하기 때문에 말더듬 치료 시 집단 치료나 자조그룹을 통해 PWS가 서로에게 도움을 받을 수 있다는 것을 알지 못했을 수 있다.

'잠재력'의 점수는 연령과 성별에 관계없이 높게 나타났다. 이는 일반인이 사회적 성취 혹은 직업적 성공과 관련하여 PWS에게 부
정적인 신념이 적음을 의미한다. 특히 “친구를 사귈 수 있다”와 “평 범한 삶을 살 수 있다"는 것에 동의한 응답자의 비율은 $80 \%$ 이상으 로 PWS의 사회적 성취에 긍정적인 반응을 보였다. 하지만 직업적 인 측면과 관련된 문항에 동의한 비율이 $50 \%$ 가 넘기는 하였지만 사회적 측면에 비해서는 다소 낮은 결과를 보였다. 이는 PWS가 직 업적 선택이나 성취와 관련하여 제한을 받는다는 청자의 신념을 보고했던 선행연구 결과와 맥락을 같이 한다(Abdalla \& St. Louis, 2014; Gabel et al., 2004; Hurst \& Cooper, 1983). 실제 Klein과 Hood (2004)는 PWS가 자신의 말더듬으로 인해 직장을 얻을 수 없었다 는 설문조사 결과를 보고하기도 하였다. 말에 문제가 있으므로 직 업적인 제한이 필요하다고 생각하거나 중요한 사항을 이해하고 결 정하는 직업을 갖는 것이 어려울 것이라는 부정적인 신념은 직장에 서 PWS의 능력을 과소평가하게 될 수 있으며, PWS가 직장에서 자 신의 능력을 발휘하는 데 잠재적인 걸림돌이 될 수 있다. 또한 이러 한 신념이 편견이나차별과 같은 정서적/행동적 반응으로 나타나게 된다면 결과적으로 PWS의 활동/참여의 제한을 야기하고 삶의 질 을 감소시키게 될 것이다.

서론에서 기술하였듯이 말더듬 고정관념 및 신념과 관련하여 인 구통계학적 변인인 연령과 성별의 영향은 일관된 결론에 이르지 못 하고 있다. 국내 일반인을 대상으로 이루어진 본 연구에서는 POSHA-S의 '도움의 출처' 구성요소 점수를 제외하면 말더듬 고정관 념과 신념에 연령에 따른 차이가 나타나지 않았다. 연령이 높아질 수록 PWS에 대한 신념이 긍정적이었다고 보고한 Arnold 등(2015) 은 연령이 증가하면서 다양한 인간관계와사회생활을 통해 응답자 가 PWS를 경험할 수 있는 기회가 증가할 수 있었기 때문으로 해석 하였다. 하지만 이 연구에 참여했던 응답자 연령대의 평균은 36.11 세 $( \pm 15.34)$ 였으며, 집단 간 비교가 아니었기 때문에 본 연구 결과 와 직접적인 비교는 어려워 보인다. 연령대별 비교를 실시하여 높은 연령대의 신념이 부정적이었음을 보고했던 de Britto Pereira 등(2008) 역시 비교 연령집단이 21세 미만, 21-55세, 55세 이상으로 각 연령대 별 비교를 실시했던 본 연구 결과와는 직접적인 비교가 어려웠다. 하지만, 전체 11 개 문항 중 아이가 말을 더듬는 경우 어떻게 할 것인 지에 대한 문항에서만 55세 이상 연령집단이 언어재활사에게 상담 을 받겠다고 응답한 비율이 유의하게 낮았던 것으로 나타나 전반 적으로 연령집단에 따른 신념의 차이는 많지 않았었다. 성별의 경 우도 마찬가지로 국내 연구에서는 남성과 여성의 고정관념이나 신 념이 크게 다르지 않은 것으로 나타났다. 성별에 따른 PWS에 대한 신념의 차이를 보고하였던 연구는 여성이 남성보다 어떠한 특정 대 상에 대해 보이는 공감(empathy)능력이 크기 때문이라고 해석하기 도 하였으며(Arnold et al., 2015), 특정 연령대에서만 성별의 차이가 
나타날 수 있다고 보고하였으나(Schlagheck et al., 2009) 서론에서 기술하였듯이 성별에 따른 차이가 없었음을 보고한 연구들 또한 다수이기 때문에 성별에 따른 고정관념이나 신념 관련해서는 추가 적인 연구가 필요해 보인다. 하지만 이번 연구 결과는 연령과 성별이 전반적인 말더듬 관련 고정관념과 신념에 중요한 영향을 미치는 변 인이라고 하기에는 무리가 있을 수 있음을 시사한다.

말더듬 관련 지식을 측정하는 ASK 결과 역시 연령과 성별에 상 관없이 평균점수가 비슷하게 나타났다. ASK를 사용한 선행연구들 은 26개 검사문항을 그대로 사용하였으므로(Crowe \& Cooper, 1977; Crowe \& Walton, 1981; Tomczyk, 2004) 23개 문항을 사용하 였던 본 연구의 결과와 직접적인 비교는 어렵지만, 본 연구의 평균 정답률이 약 55\% 정도로 평균 정답률이 61.5\%-67\%였던 Crowe와 Cooper (1977)의 결과보다는 다소 낮게 나타났다. 이는 국내 일반 인이 말더듬과 관련한 지식/경험이 적고 말더듬 관련 정보를 찾아 보려 시도한 경우가 낮았음을 보고했던 Chon (2016)과 그 맥락을 같이한다. 일반인이 말더듬에 관심을 갖고 관련 정보나 지식을 스 스로 찾기 위해서는 이와 관련된 동기부여가 이루어져야 하는데, 일반인에게는 이러한 동기부여가 이루어지기 어렵기 때문이다. 또 한 ASK는 POSHA-S의 구성요소 중 '말더듬의 원인'과 ‘잠재력' 점 수와 통계적으로는 유의하지만 상관의 정도가 매우 낮게 나타났 다. '말더듬의 원인'에 속한 문항들이 다른 구성요소에 비해 상대적 으로 객관적인 판단이 가능하며 ASK의 문항 중 말더듬의 원인과 관련 있는 문항이 있었던 것이 이번 결과에 영향을 끼쳤을 수 있을 것이다. 또한 말더듬에 대한 지식이 높을수록 PWS의 잠재적 가능 성을 좀 더 긍정적으로 보는 경향이 있었을 수 있다. 하지만 상관계 수가 매우 낮았기 때문에 해석에 주의가 필요할 것으로 보인다. 또한 말더듬 관련 지식과 ‘특성/성격, '도움의 출처', 하위범주인 'PWS에 대한 신념' 점수와는 상관계수가 무시할만한 수준으로 나타났다. 이는 일반인에게 말더듬과 관련된 이론적인 지식이나 정보를 제공 하는 것만으로는 PWS에 대한 부정적인 고정관념이나 신념의 감소 나 변화를 직접적으로 기대하기는 어려울 수 있음을 시사한다(Sim, 2000). 최근 문헌들은 말더듬과 관련된 정보제공을 일반인이 관심 을 가질만한 다양한 방법으로 제공하고 있다. 말더듬 관련 정보를 영상자료를 통해 제공하거나(Abdalla \& St. Louis, 2014) 교육 시 말 을 더듬는 사람과 직접 만나서 말더듬에 대한 이야기를 듣는 방법 을 사용한(Flynn \& St. Louis, 2011) 연구들은 이러한 방법이 PWS 에 대한 태도 변화에 긍정적인 영향을 미쳤음을 보고하였다. 이러 한 결과들은 말을 더듬지 않는 일반인, 학생, 교사 등을 대상으로 이루어지는 말더듬에 대한 교육방법이 변화되어야 함을 시사한다. 1998년부터 지속되고 있는 국내외의 말더듬 인식의 날(Interna- tional Stuttering Awareness Day) 워크솝도 일반인 교육을 위한 하 나의 방법이 될 수 있을 것이다. 또한 미국 말더듬 재단(Stuttering Foundation of America)이나 최근 국내에 설립된 '말더듬과 함께 하는 사회적 협동조합(http://www.withstuttering.org/)'과 같은 단 체의 조직적인 활동을 통해 말더듬과 관련된 지식적인 측면을 다 양한 방법으로 제공할 수 있을 것이라 기대한다.

본 연구의 제한점과 후속연구를 위한 제언은 다음과 같다. 본 연 구는 인구통계학적인 변인 중 성별과 연령을 독립변수로, 교육 연 수와 PWS와의 친숙성을 잠재적인 가외변수로 선정하였으나 전반 적으로 성별과 연령에 따른 고정관념, 신념과 지식의 차이가 나타 나지 않았으며 가외변수 역시 종속변수와 유의한 상관이 없었던 것 으로 나타났다. 후속 연구에서는 보다 다양한 인구통계학적 변인 을 고려한 연구가 필요할 것이다. 예를 들어, 말더듬과 관련된 대중 매체 노출 정도에 따른 PWS에 대한 고정관념과 신념에 대한 연구 는 대중매체가 응답자의 인식에 어느 정도 영향을 미치는지 파악 할 수 있게 해줄 것이다. 또한 PWS와의 친숙성 정도를 세분화시켜 집단별 비교가 가능할 것이다. 본 연구에서는 PWS를 전혀 알지 못 한다고 보고했던 응답자가 전체의 $49 \%$ 로 많은 비율을 차지했었기 때문에 PWS 와의 친숙성이 가외변수로 영향을 미치기 어려웠을 수 있다. 따라서 PWS에 대한 친숙성을 기준으로 한 집단별 비교는 PWS에 대한 고정관념이나 신념 관련하여 임상적으로 의미 있는 정보를 제공할 수 있을 것이다.

또한 본 연구는 표본선정 시 비확률적 표집방법을 사용하였기 때문에 연구 결과를 일반화하기에는 한계가 있었다(Sung \& Si, 2014). 확률적 표집을 위해서는 전화번호나 주소뿐만 아니라 본 연 구의 독립변수였던 연령대와 성별과 같은 일반인의 개인정보를 사 용한 표집목록 작성이 이루어져야 하지만 본 연구에서는 개인정보 를 사용하여 일반인과 임의적으로 접촉하는 것이 불가능하였기 때문이다. 추후 확률적 표집방법을 통한 후속 연구가 이루어진다 면 PWS에 대한 국내 일반인의 고정관념과 신념 특성을 더욱 일반 화시킬 수 있을 것이다.

\section{REFERENCES}

Abdalla, F., \& St. Louis, K. O. (2014). Modifying attitudes of Arab school teachers toward stuttering. Language, Speech, and Hearing Services in Schools, 45, 14-25.

Al-Khaledi, M., Lincoln, M., McCabe, P., Packman, A., \& Alshatti, T. (2009). The attitudes, knowledge and beliefs of Arab parents in Kuwait about stuttering. Journal of Fluency Disorders, 34, 44-59. 
Arnold, H. S., Li, J., \& Goltl, K. (2015). Beliefs of teachers versus non-teachers about people who stutter. Journal of Fluency Disorders, 43, 28-39.

Blood, G. W., Blood, I. M., Tellis, G., \& Gabel, R. (2001). Communication apprehension and self-perceived communication competence in adolescents who stutter. Journal of Fluency Disorders, 26, 161-178.

Boyle, M. P. (2013). Assessment of stigma associated with stuttering: development and evaluation of the Self-Stigma of Stuttering Scale (4S). Journal of Speech, Language, and Hearing Research, 56, 1517-1529.

Boyle, M. P., Blood, G. W., \& Blood, I. M. (2009). Effects of perceived causality on perceptions of persons who stutter. Journal of Fluency Disorders, 34, 201-218.

Burley, P. M., \& Rinaldi, W. (1986). Effects of sex of listener and of stutterer on ratings of stuttering speakers. Journal of Fluency Disorders, 11, 329-333.

Bushey, T., \& Martin, R. (1988). Stuttering in children's literature. Language, Speech, and Hearing Services in Schools, 19, 235-250.

Chon, H. (2016). Self-reactions of the public toward people who stutter: age and sex differences. Communication Sciences \& Disorders, 21, 371-381.

Chon, H., \& Yaruss, J. S. (2015). A preliminary study on the development of the Korean version of the Overall Assessment of the Speaker's Experience of Stuttering (OASES) for adults. Journal of Speech-Language \& Hearing Disorders, 24, 145-155.

Corrigan, P. W., \& Watson, A. C. (2002). The paradox of self-stigma and mental illness. Clinical Psychology: Science and Practice, 9, 35-53.

Corrigan, P. W., Larson, J. E., \& Rüsch, N. (2009). Self-stigma and the "why try" effect: impact on life goals and evidence-based practices. World Psychiatry, 8, 75-81.

Craig, A., Blumgart, E., \& Tran, Y. (2009). The impact of stuttering on the quality of life in adults who stutter. Journal of Fluency Disorders, 34, 61-71.

Craig, A., Tran, Y., \& Craig, M. (2003). Stereotypes towards stuttering for those who have never had direct contact with people who stutter: a randomized and stratified study. Perceptual and Motor Skills, 97, 235-245.

Crowe, T. A., \& Cooper, E. B. (1977). Parental attitudes toward and knowledge of stuttering. Journal of Communication Disorders, 10, 343-357.

Crowe, T. A., \& Walton, J. H. (1981). Teacher attitudes toward stuttering. Journal of Fluency Disorders, 6, 163-174.

de Britto Pereira, M. M., Rossi, J. P., \& Van Borsel, J. (2008). Public awareness and knowledge of stuttering in Rio de Janeiro. Journal of Fluency Disorders, 33, 24-31.

Doody, I., Kalinowski, J., Armson, J., \& Stuart, A. (1993). Stereotypes of stutterers and nonstutterers in three rural communities in Newfoundland. Jour- nal of Fluency Disorders, 18, 363-373.

Fiske, S. T. (1998). Stereotyping, prejudice, and discrimination. In T. D. Gilbert, S. T. Fiske, \& G. Lindzey (Eds.), The handbook of social psychology (4th ed., pp. 357-411). Boston: McGraw-Hill.

Flynn, T. W., \& St. Louis, K. O. (2011). Changing adolescent attitudes toward stuttering. Journal of Fluency Disorders, 36, 110-121.

Gabel, R. M., Blood, G. W., Tellis, G. M., \& Althouse, M. T. (2004). Measuring role entrapment of people who stutter. Journal of Fluency Disorders, 29, 27-49.

Goffman, E. (1963). Stigma: notes on the management of spoiled identity. Englewood Cliffs, NJ: Prentice Hall.

Hughes, S., Gabel, R., Irani, F., \& Schlagheck, A. (2010). University students' explanations for their descriptions of people who stutter: an exploratory mixed model study. Journal of Fluency Disorders, 35, 280-298.

Hurst, M. I., \& Cooper, E. B. (1983). Employer attitudes toward stuttering. Journal of Fluency Disorders, 8, 1-12.

Jin, X. M., Zhao, J., Zhang, Y. W., \& Van Borsel, J. (2001). Public awareness of stuttering in Shanghai, China. Logopedics Phoniatrics Vocology, 26, 145-150.

Kalinowski, J., Stuart, A., \& Armson, J. (1996). Perceptions of stutterers and nonstutterers during speaking and nonspeaking situations. American Journal of Speech-Language Pathology, 5, 61-67.

Kim, H. (2013). Completing statistical analyses single-handed: from analyses to writing reports. Seoul: Hakjisa.

Klassen, T. R. (2001). Perceptions of people who stutter: re-assessing the negative stereotype. Perceptual and Motor Skills, 92, 551-559.

Klassen, T. R. (2002). Social distance and the negative stereotype of people who stutter. Journal of Speech Language Pathology and Audiology, 26, 9099.

Klein, J. F., \& Hood, S. B. (2004). The impact of stuttering on employment opportunities and job performance. Journal of Fluency Disorders, 29, 255273.

Ko, Y. (2015). Elementary schoolteachers' knowledge, perceptions and attitudes towards stuttering by the experience of teaching students who stutter (Master's thesis). Chosun University, Gwangju, Korea.

Lass, N. J., Ruscello, D. M., Pannbacker, M. D., Schmitt, J. F., \& Everly-Myers, D. S. (1989). Speech-language pathologists' perceptions of child and adult female and male stutterers. Journal of Fluency Disorders, 14, 127-134.

Lass, N. J., Ruscello, D. M., Pannbacker, M., Schmitt, J. F., Kiser, A. M., Mussa, A. M., ... \& Lockhart, P. (1994). School administrators' perceptions of people who stutter. Language, Speech, and Hearing Services in Schools, 25, 90- 
93.

Lass, N. J., Ruscello, D. M., Schmitt, J. F., Pannbacker, M. D., Orlando, M. B., Dean, K. A., ... \& Bradshaw, K. H. (1992). Teachers' perceptions of stutterers. Language, Speech, and Hearing Services in Schools, 23, 78-81.

Lee, K. (2013). Perception toward stuttering by teachers in Daegu area. Communication Sciences \& Disorders, 18, 447-458.

Lee, K. (2014). Korean speech-language pathologists' attitudes toward stuttering according to clinical experiences. International Journal of Language \& Communication Disorders, 49, 771-779.

Link, B. G., \& Phelan, J. C. (2006). Stigma and its public health implications. Lancet, 367, 528-529.

MacKinnon, S. P., Hall, S., \& MacIntyre, P. D. (2007). Origins of the stuttering stereotype: stereotype formation through anchoring-adjustment. Journal of Fluency Disorders, 32, 297-309.

Park, K. R., \& Yi, Y. (2001). Stereotypes of the elderly held by university students. Journal of the Korean Gerontological Society, 21, 71-83.

Patterson, J., \& Pring, T. (1991). Listeners attitudes to stuttering speakers: no evidence for a gender difference. Journal of Fluency Disorders, 16, 201-205.

Ruscello, D. M., Lass, N. J., Schmitt, J. F., \& Pannbacker, M. D. (1994). Special educators' perceptions of stutterers. Journal of Fluency Disorders, 19, 125132.

Schlagheck, A., Gabel, R., \& Hughes, S. (2009). A mixed methods study of stereotypes of people who stutter. Contemporary Issues in Communication Sciences and Disorders, 36, 108-117.

Shin, M. (2011). Factors related to stuttering onset in Korean children who stutter. Korean Journal of Communication Disorders, 16, 103-113.

Sim, H. S. (2000). A study on stereotypes of the Korean male adults who stutter. Korean Journal of Communication Disorders, 5, 192-208.

Smith, A., \& Kelly, E. (1997). Stuttering: a dynamic, multifactorial model. In R. F. Curlee \& G. M. Siegel (Eds.), Nature and treatment of stuttering: new directions (2nd ed., pp. 204-217). Boston: Allyn and Bacon.

St. Louis, K. O. (2005). A global project to measure public attitudes of stuttering. The ASHA Leader, 10, 12-13.

St. Louis, K. O. (2012a). Research and development on a public attitude instrument for stuttering. Journal of Communication Disorders, 45, 129-146. St. Louis, K. O. (2012b). Male versus female attitudes toward stuttering. Jour- nal of Communication Disorders, 45, 246-253.

St. Louis, K. O., Filatova, Y., Coşkun, M., Topbaş, S., Özdemir, S., Georgieva, D., ... \& George, R. D. (2011). Public attitudes toward cluttering and stuttering in four countries. In E. L. Simon (Ed.), Psychology of stereotypes (pp. 81-105). Hauppauge, NY: Nova Science Publishers.

St. Louis, K. O., Lubker, B. B., Yaruss, J. S., \& Aliveto, E. F. (2009). Development of a prototype questionnaire to survey public attitudes toward stuttering: reliability of the second prototype. Contemporary Issues in Communication Sciences and Disorders, 36, 101-107.

St. Louis, K. O., Reichel, I. K., Yaruss, J. S., \& Lubker, B. B. (2009). Construct and concurrent validity of a prototype questionnaire to survey public attitudes toward stuttering. Journal of Fluency Disorders, 34, 11-28.

Sung, T., \& Si, G. (2014). Research methodology (2nd ed.). Seoul: Hakjisa.

Tomczyk, D. A. (2004). The perceptions of psychotherapists-in-training regarding people who stutter versus normally fluent speakers (Doctoral dissertation). University of North Texas, TX.

Van Borsel, J., Verniers, I., \& Bouvry, S. (1999). Public awareness of stuttering. Folia Phoniatrica et Logopaedica, 51, 124-132.

Weisel, A., \& Spektor, G. (1998). Attitudes toward own communication and toward stutterers. Journal of Fluency Disorders, 23, 157-172.

White, P. A., \& Collins, S. R. (1984). Stereotype formation by inference: a possible explanation for the stutterer stereotype. Journal of Speech, Language, and Hearing Research, 27, 567-570.

Woods, C. L., \& Williams, D. E. (1976). Traits attributed to stuttering and normally fluent males. Journal of Speech, Language, and Hearing Research, $19,267-278$.

World Health Organization (2001). International Classification of Functioning, Disability and Health (ICF). Geneva: Author.

Yairi, E., \& Ambrose, N. G. (2005). Early childhood stuttering for clinicians by clinicians. Austin, TX: Pro-Ed.

Yairi, E., \& Williams, D. E. (1970). Speech clinician's stereotypes of elementary-school boys who stutter. Journal of Communication Disorders, 3, 161170 .

Yaruss, J. S., \& Quesal, R. W. (2004). Stuttering and the International Classification of Functioning, Disability, and Health (ICF): an update. Journal of Communication Disorders, 37, 35-52. 


\section{국문초록}

\section{말더듬는 사람에 대한 일반인의 신념과 지식: 연령과 성별 비교 전희정}

조선대학교 언어치료학과

배경 및 목적: 본 연구는 일반인이 말더듬는 사람(PWS)에게 보이는 신념과 지식의 정도를 연령과 성별에 따른 비교를 통해 구체적으 로 파악하고, 신념과 지식 사이의 상관을 살피는 것을 목적으로 하였다. 방법: 연구 대상은 298 명의 일반 성인이었다. 대상자는 POSHA-S의 하위범주인 'PWS에 대한 신념'에 속한 문항과 Alabama 말더듬 지식 검사(ASK) 문항에 답하였다. POSHA-S에 응답한 자료 는 '특성/성격, '도움의 출처', '말더듬의 원인', '잠재력'의 네 개 구성요소로 분석하였으며, 구성요소의 평균을 계산하여 'PWS에 대한 신념’ 점수를 산출하였다. 대상자의 ASK 점수에 대한 분석도 함께 이루어졌다. 결과: POSHA-S의 'PWS에 대한 신념' 점수와 그 구성 요소인 ‘특성/성격, '말더듬의 원인' ‘잠재력' 점수는 연령과 성별에 따른 차이를 보이지 않았다. 하지만 ‘도움의 출처’는 50대 이상 집단 이 20대 집단보다 유의하게 높은 점수를 보였다. ASK 점수는 연령과 성별에 따른 차이를 보이지 않았으나, 'PWS에 대한 신념'의 구성요 소인 '말더듬의 원인'과 ‘잠재력’ 점수와 유의하지만 낮은 정적상관을 보였다. 논의 및 결론: PWS에 대한 일반인의 신념은 연령과 성별 에 관계없이 중립에 가까운 모습을 보였지만 각 구성요소 내에서 일반인이 가지고 있는 PWS에 대한 부정적인 신념을 확인할 수 있었다. 따라서 단순히 말더듬 관련 지식을 제공하는 것보다는 다양한 방법을 통해 일반인이 PWS에 대한 부정적 신념을 감소시킬 수 있도록 해야 할 것으로 보인다.

핵심어: 말더듬는 사람(PWS), 신념, 지식, POSHA-S, 연령, 성별

\section{참고문헌}

고영범(2015). 말더듬 학생 교육경험 유무에 따른 초등학교 교사의 말더듬에 대한 지식과 인식 및 태도. 조선대학교대학원 석사학위논문.

김효창(2013). 혼자서 완성하는 통계분석: 분석에서 보고서 작성까지. 서울: 학지사.

박경란, 이영숙(2001). 대학생이 갖고 있는 노인에 대한 고정관념 분석. 한국노년학, 21, 71-83.

성태제, 시기자(2014). 연구방법론(2판). 서울: 학지사.

신문자(2011). 아동 말더듬 시작과 관련된 요인의 특성. 언어청각장애연구, 16, 103-113.

심현섭(2000). 한국 말더듬 성인에 대한 고정관념 연구. 언어청각장애연구, 5, 192-208.

이경재(2013). 대구지역 교사의 말더듬에 대한 인식. 언어청각장애연구, 18,447-458.

전희정(2016). 연령과 성별에 따른 일반인의 말더듬는 사람에 대한 자기반응 비교. 언어청각장애연구, 21, 371-381.

전희정, 스콧 야루스(2015). 성인용 전반적 말더듬 경험 평가(OASES)의 국내적용을 위한 기초 연구: 타당도와 신뢰도를 중심으로. 언어치료연구, 24, 145-155. 